\title{
Correlation of quantitative HBSAG with quantitative HBV DNA in different phases of chronic hepatitis $b$ (CHB) patients
}

\begin{abstract}
Background: Quantitative HBsAg (qHBsAg) level is increasingly recognized as an important marker in the course of HBV infection; however, its role in natural history of disease is still unclear.

Aim: To study the baseline serum qHBsAg level and its association with quantitative HBV DNA levels in different phases of Indian chronic hepatitis B (CHB) patients.

Materials: We conducted cross-sectional study of consecutive 120CHB patients (mean age 37 [SD 13]years, 67\% males). HBV DNA was measured by RT PCR and serum qHBsAg levels by Abott Architect Assay.

Results: $90.8 \%$ were $\mathrm{HBe}-$ negative patients. Median serum qHBsAg of study cohort was $3.74 \log 10 \mathrm{IU} / \mathrm{mL}$. Overall correlation between qHBsAg levels and HBV DNA levels was weak (spearmen $r=0.298$ ) and also in HBe-negative patients $(r=0.179)$. Patient having $\mathrm{qHBs}$ Ag/HBV DNA ratio $>49.09$ have shown good correlation between qHBsAg levels and HBV DNA levels.

Conclusion: Quantitative HBsAg level was widely distributed among the different phases of CHB. Serum qHBsAg may not replace serum HBV DNA test in majority of adult $\mathrm{CHB}$ population which are mainly in $\mathrm{HBe}$-negative low replicate stage.
\end{abstract}

Keywords: chronic hepatitis b, quantification HBSAG, HBV DNA, correlation
Volume I Issue $3-2016$

\author{
Hrishikesh Samant,' Anand Joshi,' Philip \\ Abraham,' Devendra Desai,' Tarun Gupta,' \\ Deshpande ${ }^{2}$ \\ 'Division of Gastroenterology, P.D. Hinduja National Hospital \\ and Medical Research Centre, India \\ ${ }^{2}$ Department of blood bank medicine, P.D. Hinduja National \\ Hospital and Medical Research Centre, India
}

Correspondence: Hrishikesh Samant, Division of

Gastroenterology, P.D. Hinduja National Hospital and Medical Research Centre, Veer Savarkar Marg, Mahim, Mumbai, India 400 016,Tel 4023785304, Email samanthrishi@gmail.com

Received: November 15, 2015 | Published: January 09, 2016
Abbreviations: CHB, chronic hepatitis B; qHBsAG, quantitative HBsAg; CCC, covalently closed circular; HBsAg, hepatitis b surface antigen; IT, immune tolerant; ULN, upper limit normal; IC, immune clearance; LR, low replicative; ENH, hbeagnegative hepatitis.

\section{Introduction}

Hepatitis B continues to be a major health problem across the world, especially in developing countries. As we know the test for hepatitis B surface antigen (HBsAg) was introduced more than 20years ago, due to lack of appropriate standardisation HBsAg has long been used as a qualitative marker for diagnosis of hepatitis B. ${ }^{1}$ Recently, an automated chemiluminescent micro particle immunoassay for detection of HBsAg became available in India and offered more reliable quantification of $\mathrm{HBsAg} .{ }^{2}$ Since $\mathrm{HBsAg}$ levels correlate with intrahepatic covalently closed circular (CCC) HBV DNA, the surrogate marker of the infected cell, it appears that serum HBsAg levels may be a valuable addition to HBV DNA in the management of patients with chronic hepatitis $\mathrm{B}(\mathrm{CHB}) .{ }^{3,4}$

New data on HBsAg quantification (qHBsAg) is emerging, and it is becoming apparent that information on HBsAg levels can add to our understanding of both the natural history of the disease and its response to treatment. Recent studies have described the clinical utility of HBsAg quantification. ${ }^{5-8}$ Few studies have compared quantitative HBsAg and HBV DNA during natural history of the disease. Results of these are conflicting. Studies by Kuhns et al. ${ }^{9}$ and Mukherjee et al. ${ }^{10}$ had shown no correlation between qHBsAg and HBV DNA, while Ozdil et al. ${ }^{11}$ reported a negative correlation between two. There is paucity of data regarding serum HBsAg levels in different phases of treatment-naïve chronic hepatitis B.

The aim of our study was to learn more about the kinetics of serum HBsAg levels and its correlation with HBV DNA levels during the natural history of infection in Indian chronic hepatitis B patients.

\section{Materials and methods}

We studied all consecutive treatment-naïve adult HBsAgpositive subjects presented between July 2011 and July 2012 in the Gastroenterology department of tertiary-care hospital. Patients with HIV or anti-HCV positivity, history of significant alcohol intake (more than 20g alcohol/day) or hepatotoxic drugs within last 6months prior to enrolment, history chronic liver disease due to causes other than hepatitis B or undetectable HBV DNA were excluded.

Demographic features and clinical presentations were noted in a spreadsheet. All subjects underwent liver biochemistry using a Beckman kit and auto-analyser (Beckman Coulter, Inc, USA). Normal ALT was defined as up to 40IU/L as per the manufacturer's recommendation; values more than $40 \mathrm{IU} / \mathrm{L}$ were taken as elevated. Serological tests have done include $\mathrm{HBeAg}$ and anti-HBe using the mini-VIDAS kit (BioMerieux, Inc, USA). Test for HBV DNA was done using real-time polymerase chain reaction (COBAS TaqMan; Roche Diagnostics, Indianapolis, IN, USA); the lower limit of detection was $0.4 \mathrm{IU} / \mathrm{mL}$. HBsAg quantification (qHBsAg) was done by Abbott Architect assay (Dr. Lal Pathlabs- National reference lab at New Delhi, India). All patients were counselled and advised to have family members and household contacts screened for HBsAg. 
The chronic hepatitis B phase was determined for each patient after evaluating liver function test over one year, HBe antigen status and HBV DNA levels as: Immune tolerant (IT) phase, defined as $\mathrm{HBeAg}$ positive, high viral load ( $>20000 \mathrm{IU} / \mathrm{ml}$ ), serum ALT $<2 \mathrm{X}$ upper limit normal (ULN), Immune clearance (IC) phase, defined as $\mathrm{HBeAg}$ positive, $\mathrm{HBV}$ DNA $>20000 \mathrm{IU} / \mathrm{ml}$, serum ALT $>2 \mathrm{X}$ ULN, Low replicative (LR) phase, defined as $\mathrm{HBeAg}$ negative, HBV DNA $<2000 \mathrm{IU} / \mathrm{mL}$, normal serum ALT and HBeAg-negative hepatitis (ENH) phase, defined as HBeAg negative, HBV DNA >2000IU/ $\mathrm{mL}$, serum ALT $>2$ X ULN. Correlation between HBV DNA and quantitative HBsAg was studied within each phase.

\section{Statistical methods}

Numerical variables are represented in the form of mean as well as median or inter-quartile range whenever applicable. Qualitative data are represented by means of frequency and percentage. Correlation was analysed using the non-parametric two-tailed Spearman rank correlation test where variables are not normally distributed. All $\mathrm{p}$ values less than 0.05 are considered significant. Numerical data were calculated using Microsoft Excel and analysed using SPSS version 16 software package (SPSS, Inc., Chicago, IL, USA).

\section{Results}

A total of 120 treatment-naïve HBsAg-positive patients (80men, $66.6 \%$; aged 25 to 49 , mean 37) were evaluated during the study period. Cirrhosis was present in 9 and hepatocellular carcinoma was diagnosed in 2(1.6\%) patients on Imaging. Ultrasonography findings were normal in $96(80 \%)$ subjects. During screening of family members, HBsAg positivity was found in $24(20 \%)$ subjects.

On serological testing, of the 120HBsAg-positive subjects, 109(90.8\%) were HBe-negative and 11(9.6\%) were HBe-positive. On further classifying into phases of chronic hepatitis B, 4(3.3\%) subjects were in immune-tolerant phase, $7(5.8 \%)$ in immune-reactive phase, $96(80 \%)$ in low-replicative phase, and $13(10.8 \%)$ had HBe-negative hepatitis. The male female ratio, mean age, and the mean ALT values, median quantitative HBV DNA (IU/ml) and median quantitative HBsAg (IU/ml) are shown in Table 1.

Table I Baseline characteristics in the four phases

\begin{tabular}{|c|c|c|c|c|}
\hline & Immune tolerant $(n=4)$ & Immune reactive $(n=7)$ & Low replicative( $n=96)$ & HBe-negative hepatitis( $n=\mid 3)$ \\
\hline Age (yr) & $28.2 \pm 13.6$ & $39.5 \pm 15.6$ & $36.2 \pm 12.2$ & $42.2 \pm 12.9$ \\
\hline Gender (M:F) & $3: 01$ & $6: 01$ & $63: 33: 00$ & $8: 05$ \\
\hline ALT(IU/L) & $4 I \pm 14$ & $373 \pm 676.2$ & $33.5 \pm 18.2$ & $42.2 \pm 66.5$ \\
\hline $\begin{array}{l}\text { Median HBV } \\
\text { DNA (IU/ml) }\end{array}$ & $9.6(0.089$ to 170$) \times 106$ & $1.7(0.21$ to 1.7$) \times 108$ & $4.64(0.02$ to 157$) \times 102$ & $5.15(0.30$ to 200$) \times 104$ \\
\hline $\begin{array}{l}\text { Median qHBsAg } \\
(\mathrm{IU} / \mathrm{ml})\end{array}$ & $\begin{array}{l}4.24 \log 10 \mathrm{IU} / \mathrm{ml} \\
(0.29 \text { to } \mathrm{II} .5) \times 104 \mathrm{IU} / \mathrm{ml}\end{array}$ & $\begin{array}{l}4.06 \log 10 \mathrm{IU} / \mathrm{ml} \\
(0.025 \text { to } 12.5) \times 104 \mathrm{IU} / \mathrm{ml}\end{array}$ & $\begin{array}{l}3.7 \mathrm{I} \log 10 \mathrm{IU} / \mathrm{ml} \\
(0.1 \text { to } 537) \times 104 \mathrm{IU} / \mathrm{ml}\end{array}$ & $\begin{array}{l}3.78 \log 10 \mathrm{IU} / \mathrm{ml} \\
(0.10 \text { to } 2.54) \times 104 \mathrm{IU} / \mathrm{ml}\end{array}$ \\
\hline
\end{tabular}

Median quantitative $\mathrm{HBsAg}$ of study population was $3.74 \log _{10}$ $\mathrm{IU} / \mathrm{ml}$ (range -0.1 to $5378468 \mathrm{IU} / \mathrm{ml}$ ). Median quantitative HBsAg in cirrhosis ( $\mathrm{n}=9$ ) patients was $3.41 \log _{10} \mathrm{IU} / \mathrm{ml}$ (range -0.1 to $26153 \mathrm{IU} /$ $\mathrm{ml}$ ). It was lower than median HBsAg of study population, however it did not reached statistical significance $(p=0.72)$. Median HBsAg levels among subjects with family history of hepatitis $B(n=24)$ was $3.74 \log _{10} \mathrm{IU} / \mathrm{ml}$ (range -89.67 to $125000 \mathrm{IU} / \mathrm{ml}$ ) and was similar to median HBsAg of study group.

There was a modest negative correlation between age and quantitative serum HBsAg levels $(r=-0.39, p<0.05)$. The correlation between ALT and HBsAg did not pass the test of statistical significance $(\mathrm{r}=0.045, \mathrm{p}>0.05)$.

Overall correlation between serum quantitative HBsAg levels and serum HBV DNA levels was weak, with correlation coefficient 0.29(Figure 1). In HBe-negative patients, the correlation was weak $(\mathrm{r}=0.17)$, however the correlation was strong $(\mathrm{r}=0.87)$ among small number of HBe-positive subjects (Figure 2) (Figure 3).

The ratio between HBV DNA and HBsAg ranged from 0.00051 to 62658.4 and the ratio increased exponentially over 49.09 . We took a cut-off ratio of 49.09 (87.5th percentile of total HBV DNAto-quantitative HBsAg ratio) to divide our cohort in to two groups. This was similar to a Korean study by Lee et al. ${ }^{12}$ We observed that the correlation between HBV DNA and HBsAg in the group that showed HBV DNA-to-HBsAg ratio higher than 49.09 was stronger (Spearman $\mathrm{r}=0.83, \mathrm{p}<0.001, \mathrm{n}=15$ ) than those with ratio at or below 49.09 (Spearman $\mathrm{r}=0.28, \mathrm{p}<0.001, \mathrm{n}=105$ ). This group mainly consist of $\mathrm{HBe}$-positive subjects.

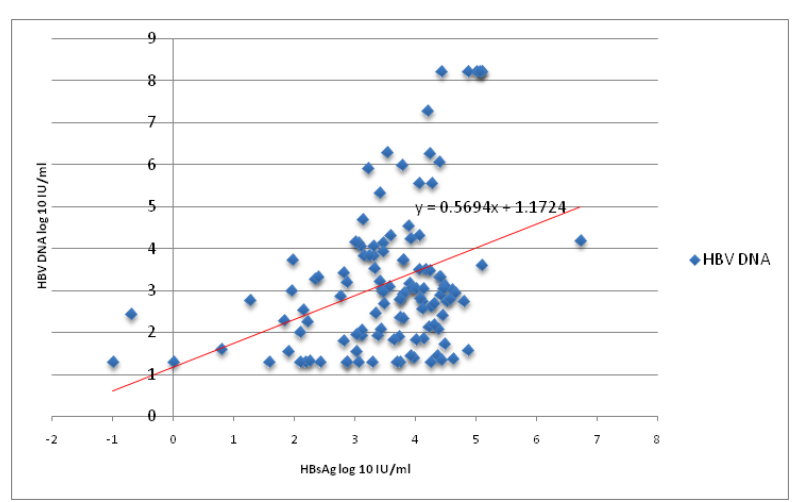

Figure I Overall correlation of $\mathrm{HBsAg}$ and $\mathrm{HBV}$ DNA.

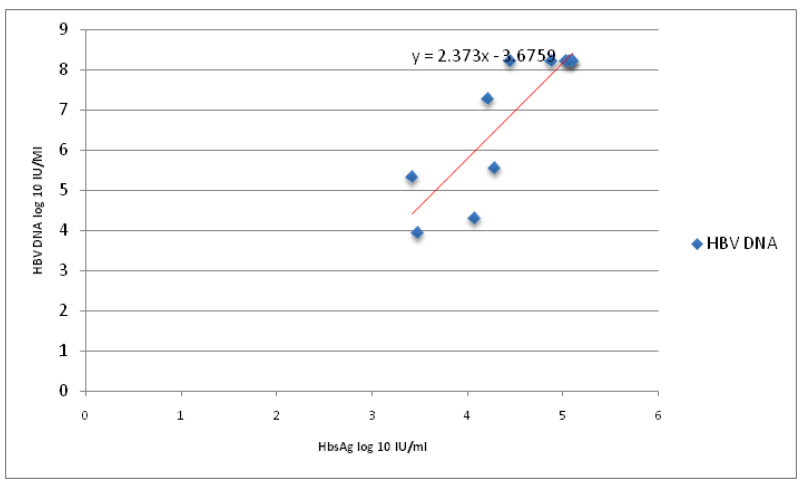

Figure 2 Correlation of $\mathrm{HBs} \mathrm{Ag}$ and $\mathrm{HBV}$ DNA in $\mathrm{H}$ Be-positive $\mathrm{CHB}$. 


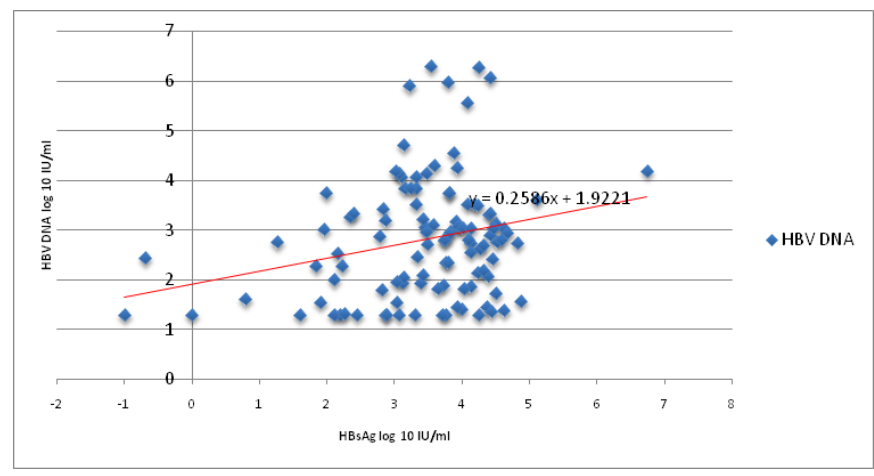

Figure 3 Correlation of $\mathrm{HBsAg}$ and HBV DNA in HBe-negative $\mathrm{CHB}$.

\section{Discussion}

Serum HBV DNA level is commonly used to monitor treatment response in the management of chronic hepatitis $\mathrm{B}$, but the test is expensive. ${ }^{13,14}$ The clinical impact of HBsAg quantification has recently drawn attention. Standardised quantitative serum HBsAg test is now available, and is relatively simple and less expensive and can be performed in a fully automated manner. Quantitative serum HBsAg correlates well with intrahepatic HBV viral DNA. ${ }^{4,15}$

We found the overall correlation between serum HBsAg and HBV DNA weak. There was a tendency for better correlation between HBsAg and HBV DNA in HBe-positive patients. This has corroborated the findings of recent study in similar cohort by Ramchandran et al. ${ }^{16}$ However, the number of HBe-positive patients fulfilling the inclusion criteria was only eleven. The correlation is weak in the lowreplicative phase, which forms the majority of our chronic hepatitis B study population. Similar results were shown by Brunetto et al. ${ }^{17}$ in their study of HBe-negative genotype D patients. Although we did not test for genotype, we expect that most samples would be of HBV genotype $\mathrm{D}$, because unpublished data from our hospital reported this genotype as the most common. This suggests that quantitative HBsAg is more related with HBV DNA levels in initial replicative phase than in later non-replicative phases.

It is difficult to compare amongst phases of chronic hepatitis B as numbers in Immune-tolerant and Immune-reactive phases were small but it's worth mentioning that median serum HBsAg levels in our study were higher in the immune-tolerant and immune-reactive phases and lower in the low-replicative and e-negative hepatitis phase. Earlier similar results have been reported in a study from Europe mainly involving genotypes $\mathrm{A}$ and $\mathrm{D}^{1}$ and also in two Korean studies of genotype C..$^{18,19}$

In our study group if patients were divided in two groups by HBV DNA-to-HBsAg ratio, with a cut-off value of 49.09(87.5th percentile), the correlation between quantitative HBsAg and HBV DNA in patients having ratio $>49.09$ was stronger compared to those having ratio less or equal to 49.09 . This is also because Hbe-positive subjects mainly had ratio $>49.09$.

The study has limitation that the number of HBe-positive patients fulfilling the inclusion criteria was few. This has restricted us from carrying any major presumptions from our HBe-positive patient cohort. Since we enrolled consecutive adult subjects, it explains the low rate of HBe positivity in our study group but also mimics real time scenario.

\section{Conclusion}

In conclusion, quantitative serum $\mathrm{HBsAg}$ test is less likely to replace serum HBV DNA test in the low replicative stage of chronic hepatitis B which forms our majority of adult CHB population.

\section{Acknowledgements}

None.

\section{Conflict of interest}

Author declares that there is no conflict of interest.

\section{References}

1. Jaroszewicz J, Calle Serrano B, Wursthorn K, et al. Hepatitis B surface antigen (HBsAg) levels in the natural history of hepatitis B virus (HBV) infection- a European perspective. J Hepatol. 2010;52(4):514-522.

2. Deguchi M, Yamashita N, Kagita M, et al. Quantitation of hepatitis $\mathrm{B}$ surface antigen by an automated chemiluminescent micro particle immunoassay. J Virol Methods. 2004;115(2):217-222.

3. Wursthorn K, Lutgehetmann M, Dandri M, et al. Peg-interferon alpha$2 \mathrm{~b}$ plus adefovir induce strong cccDNA decline and HBsAg reduction in patients with chronic hepatitis B. Hepatology. 2006;44(3):675-684.

4. Thompson AJ, Nguyen T, Iser D, et al. Serum hepatitis B surface antigen and hepatitis B e antigen titers: disease phase influences correlation with viral load and intra hepatic hepatitis B virus markers. Hepatology. 2010;51(6):1933-1944

5. MoucariR, Mackiewicz V, Lada O, et al. Early HbsAg drop: A strong predictor of sustained virological response to peglated interferon alfa-2a in HbeAg-negative patients. Hepatology. 2009;49(4):1151-1157.

6. Marcellin P, Piratvisuth T, Brunetto MR, et al. On-treatment decline in serum HBsAg levels predicts sustained immune control 1 year post treatment and subsequent $\mathrm{HBsAg}$ clearance in $\mathrm{HBeAg}$ negative hepatitis $\mathrm{B}$ virus infected patients treated with peginterferon alfa. Hepatol Int. 2010;4:151-156.

7. Wursthorn K, Jung M, Riva A, et al. Kinetics of Hepatitis B surface antigen decline during 3years of telbivudine treatment in hepatitis B e antigen-positive patients. Hepatology. 2010;52(5):1611-1620.

8. Sonneveld MJ, Rijckborst V, Boucher CA, et al. Prediction of sustained viral response to Pegylated interferon alfa- $2 b$ for $\mathrm{HBeg}$ positive chronic hepatitis B using on-treatment HBsAg decline. Hepatology. 2010;52(4):1251-1257.

9. Kuhns MC, Kleinman SH, McNamara AL, et al. Lack of correlation between HBsAg and HBV DNA levels in blood donors who test positive for HBsAg and anti-HBc: Implications for future HBV screening policy. Transfusion. 2004;44(9):1332-1339.

10. Mukherjee RM, Reddy PB, Arava J, et al. Relationship between serum HBsAg levels, HBV DNA level, and peripheral immune cells in patients with chronic hepatitis B virus infection, Hepatic Medicine: Evidence and Research. Hepat Med. 2010;2:157-162.

11. Ozdil B, Cosar AM, Akkiz H, et al. Negative correlation between viral load and HBsAg levels in chronic HBV-infected patients. Arch Virol. 2009;154(9):1451-1455.

12. Lee JH, Kim SJ, Ahn $\mathrm{SH}$, et al. Correlation between quantitative serum HBsAg and HBV DNA test in Korean patients who showed high level of HbsAg. J Clin Pathol. 2010;63(11):1027-1031.

13. Gish RG, Locarnini SA. Chronic hepatitis B: Current testing strategies. Clin Gastroenterol Hepatol. 2006;4(6):666-676. 
14. Andersson KL, Chung RT. Monitoring During and After Antiviral Therapy for Hepatitis B. Hepatology. 2009;49(5 suppl):S166-173.

15. Chan HLY, Wong VWS, Tse AML, et al. Serum hepatitis B surface antigen quantitation can reflect hepatitis B virus in the liver and predict treatment response. Clin Gastroenterol Hepatol. 2007;5(12):1462-1468.

16. Ramachandran J, Ismail AM, Chawla G, et al. Serum HBsAg quantification in treatment-naïve Indian patients with chronic hepatitis B. Indian J Gastroenterol. 2014;33(2):131-135.
17. Brunetto MR, Oliveri F, Colombatto $P$, et al. Hepatitis B surface antigen serum levels help to distinguish active from inactive hepatitis B virus genotype D carriers. Gastroenterology. 2010;139:483-490.

18. Yoo SH, Jang JW, Kwon JH, et al. Significance of hepatitis B surface antigen levels in the natural history and disease stage of hepatitis B virusrelated liver diseases in Korea. Korean J Hepatol. 2010;16(S3):S32.

19. Kim YJ, Cho HJ, Choi MS, et al. Association between quantitative HBsAg and serum HBV DNA levels in chronic hepatitis B patients [Abstract]. Liver Int. 2010;31(6):817-831. 